\title{
THE CONCEPT OF PLACE IN THE AMERICAN WEST
}

\author{
Irina CHIRICA * \\ Alexandru Ioan Cuza University of Iași, Romania
}

\begin{abstract}
This paper surveys the most significant ways in which the American West has been viewed as a place and region. Starting with Thomas Jefferson's Louisiana Purchase of 1803, we follow the expansion of the West as a region throughout American history. Jefferson worked out a plan which involved the creation of territories which later became states, following a certain procedure. Inside the larger West, there are many Wests: the prairie states of the Midwest (also called the "Bread Basket" of America), the Rocky Mountain states, the Pacific Northwest, the Southwest and California. We analyze the myths and images associated with the west in American culture, and the influence of Frederick Jackson Turner's essay dedicated to "the Frontier". We discuss the New Historicism approach and the way in which it criticizes Tuner. Then we discuss the reflection of the West in the visual arts (the major landscape painters and in the work of the western movie director John Ford). We bring arguments to support the idea that the West is a construct of human experience and a cultural concept, more than a "place".
\end{abstract}

Keywords: Western Frontier, patriotic landscape, cowboys and Indians, cultural region

\section{DEFINING THE WEST AS A PLACE AND REGION}

How could we define the West as a place and region? From the beginning, we must mention that the use of the geographical criterion to define the West does not work very well. The geographical boundaries of the West are not geographically (i.e. naturally) determined. They were culturally and politically determined. The American West is the contiguous section of the continent west of the Missouri River acquired by the United States, beginning with the Louisiana Purchase by President Thomas Jefferson in 1803, continuing with the acquisition of the Oregon territory in 1846, and the acquisition of Texas and other Mexican territories after the Mexican-American war in 1848.

\footnotetext{
*chirica_1@hotmail.com
} 
The strictly geographical explanation might distort the reality of the western environment, by making static what is dynamic. For example, geographers often use aridity to distinguish the West from other places. Over most areas of the West there is insufficient rain to grow crops without irrigation. But western Oregon, northern Washington and northern California, as well as parts of Nebraska, Oklahoma, Kansas, Texas and the Dakotas are not arid. So, we could say that aridity separates the West from the Northeast and the South, but it also divides the West itself. Inside the larger West, there are many Wests: the prairie states of the Midwest (also called the "Bread Basket" of America), the Rocky Mountain states, the Pacific Northwest, the Southwest (with its dry landscape of canyon land and the oldest in-situ Native American culture of the continent) and California.

\section{WHERE DID THE WEST BEGIN?}

Then another question comes up, and that is: Where did the West begin? We could say that at the beginning the Wild West began at the gate where the land enclosure of the Puritans ended. Outside the gate the wilderness began. Later the West began across the dividing line of the Appalachian Mountains. The British Crown signed a treaty with the Indians in 1763 , in which it was decided that the thirteen British colonies would not cross the Appalachians. In response to these the Native Americans in the Indian Reserve across the mountains obliged themselves not to behave in a hostile manner towards the colonies. Then after the American Revolution the Appalachian line border was cancelled and the West was opened for settlement, to the colonists' joy.

With the Louisiana Purchase in 1803, the United States purchased approximately 828,000,000 square miles of territory from France, doubling the size of the young republic. What was known as Louisiana Territory stretched from the Mississippi River in the east to the Rocky Mountains in the west, and from the Gulf of Mexico in the south to the Canadian border in the north. Part or all of 15 states were eventually created from the land deal, which is considered one of the most important achievements of Thomas Jefferson's presidency.

The Mexican Cession of 1848 further added to the United States the present-day states of California, Nevada, Utah, most of Arizona, half of New Mexico, a quarter of Colorado, and a small section of Wyoming. Texas, which had freed itself from Mexico in 1836 (the Siege of Alamo), was now also officially included in the United States.

Later on, the Homestead Act of 1862 continued to open the Western territory for settlement. The homestead was an area of public land in the West (usually 150 acres) granted to any US citizen willing to settle on and farm the land for at least five years. The occupant had to reside on the land for five years, and show evidence of having made improvements. 
The Oklahoma Land Rush and the Dawes Act of 1889 opened for settlement unassigned lands left vacant in the post-Civil War period. These lands were considered some of the best unoccupied public land in the nation. In reality these acts were a subterfuge for transferring Indian land into white hands. Most of the land had belonged to the Indian reservations.

The California Gold Rush further attracted people to California in 1849. Whole indigenous societies were attacked and pushed off their lands by the gold-seekers, called "forty-niners". And finally, with the settlement of California, the Americans finally ran out of land. At the edge of the Pacific, the West ended.

\section{WHEN DID THE WEST BEGIN?}

Another question we need to consider in this context will naturally be - when did the West begin? We could date the beginnings of the West from the moment when particular sections of it became part of the United States. For logical consistency, the definition ignores the Native American populations already living in the places that would become the West until the moment that the territory actually became American.

We could say that President Thomas Jefferson was the intellectual father of western settlement. Congress asked Jefferson to come up with a political way of dealing with the West. The issues they needed to confront were: what was going to be the political and government status of this area? Will the West remain a region of lesser political significance, on a lower level than the East coast, or will western territories eventually become states with an equal status with people in the East?

Thomas Jefferson wanted to build an "Empire of Liberty" stretching "from sea to shining sea". (Wood 260) He rejected the notion of North America being divided into nation-states on the European model. Jefferson wanted the principles of the American Revolution spread over the continent, shared equally by all.

Jefferson worked out a plan in which territories were created at first - a governor and at least one judge were appointed per territory. 3000 free adult males were required to vote for a territory to have its own legislature and a delegate in congress. 60.000 people of all types were required so that the territory could apply to be a state. Jefferson's plan of development was adopted in the Northwest Ordinance of 1787. Jefferson's plan became the model for the future development of the West. 


\section{THE GARDEN IN THE DESERT}

Thomas Jefferson also created the cultural image of "the garden in the desert". The cultural symbol of the garden embraced a cluster of metaphors expressing growth, fecundity and blissful labor in the earth, centered around the idealized frontier farmer armed with the supreme agrarian weapon, the sacred plow. (Smith 174)

Jefferson saw the cultivator of the earth (the yeoman or "freeman") who worked his own acres, as the rock upon which the American republic must stand. In his view, the small land holders had the independence, both economic and moral, that was indispensable in those entrusted with the solemn responsibility of franchise. Beginning in Jefferson's time, the image of the well-ordered green garden in the desert magnified to continental size and began to shape the westering process. (133)

From the time of Franklin and Jefferson down to the end of the frontier period, the West had fed on an agrarian philosophy and an agrarian myth that purported to set forth the character and destinies of the nation. The philosophy and the myth affirmed an admirable set of values, but they ceased very early to be useful in interpreting American society as a whole because they offered no intellectual apparatus for taking account of the industrial revolution. A system which revolved around a half-mystical conception of nature and held up as an ideal a rudimentary type of agriculture was powerless to confront issues arising from the advance of technology.

The myth of the garden affirmed that the dominant force in the future society of the West would be agriculture. So powerful and vivid was this cultural image that down to the very end of the 19th century it continued to seem a representation at the core of the American nation, even when the idea of the agricultural paradise of the West was undermined by negative economic and technological forces and by the aridity of the land. Drought years became more and more common at the end of the 19th century. Grasshopper plagues and blizzards raged. Crops withered in the fields. Cattle died of thirst. The furious winters of 1886 and 1887 produced stories of disasters across cow country, of ranchers going out to check their herds and find their cattle frozen to death by the hundreds, piled up against barbed wire fences, their ribs standing out because of starvation. Instead of being independent, the western farmer was at the mercy of distant and unpredictable forces: the banks, Chicago, New York and the railways. The agrarian utopia was destroyed by the land speculator and the railroad monopolist, and "the garden in the desert" was hard-hit by negative forces. 


\section{A DYNAMIC SUCCESSION OF WESTS}

Another interesting idea is that the West is actually a dynamic succession of Wests. In order to understand this phenomenon, we need to look at the concept of "the frontier". By far the most influential piece of writing about the West produced during the 19th century was the essay on The Significance of the Frontier in American History, read by Frederick Jackson Turner before the American Historical Association at Chicago in 1893.

For most of its users, the term "frontier" has been a synonym for the American nation's westward movement. Turner maintained that the West was the most important of American regions, and that the new attitudes and institutions produced by the frontier, especially through the encouragement of democracy, had been more significant in shaping American society than the imported European heritage. Turner rejected the idea that American culture and institutions were largely the product of Anglo-European influences, and looked to the things that were different about Americans.

The border of the frontier is not fixed, it is advancing constantly westwards. The westering process produced a succession of frontiers from the Appalachians to the Pacific. The wilderness beyond the frontier, the realm of savagery, it was a constantly receding area. Turner suggested that the presence of an ever-expanding frontier was to account for the uniquely American qualities. In settling the frontier, migrants created a democracy. Americans (gendered as male) were practical, egalitarian and democratic, because the successive Wests provided the "free" land on which equality and democracy could flourish.

The "westering" process discarded many European aspects that were no longer useful, for example established churches and aristocracies, intrusive government, and control of the best land by a small gentry class. Every generation moved further west and became more American, and the settlers became more democratic and less tolerant of hierarchy. They also became more violent, more individualistic and distrustful of authority, less artistic, less scientific, and more dependent on ad-hoc organizations they formed themselves. In broad terms, the further west, the more American the community.

Turner's frontier ran almost entirely on an East-to-West track. The Eastto-West understanding of the "frontier" concept cannot do justice to the prior presence of Native Americans (with their migrations), to the northward movement of Spanish-speaking people, or to the eastward movement of Asians. The "frontier" is an ethnocentric concept which overlooked for decades the fact that the frontier had two sides, the Anglo-American side and the other side of the frontier. Jammed into the other side were Indians of all tribes (often tribes that fought against each other), long-term Hispano settlers, and more recent Mexican 
immigrants. In reality, the people on the other side of the frontier did not form anything remotely resembling a unified team or homogeneous society.

What emerges is not Turner's essential progression from savagery to civilization, but rather a hybrid culture. This meeting and melding of cultures, which in America was magnified on the frontier, seems to be the most historically significant aspect of the West.

"The frontier" is also present in the discourse of United States presidents. In July 1960, President John Kennedy accepted his presidential nomination with an inaugural speech steeped in frontier rhetoric:

From the lands that stretch three thousand miles behind me, the pioneers of old gave up their safety, their comfort, and sometimes their lives to build a new world here in the West... They were determined to make the new world strong and free, to overcome its hazards and hardships, to conquer the enemies that threatened from within and without. Beyond the frontier are the uncharted areas of science and space, unsolved problems of peace and war, unconquered pockets of ignorance and prejudice. It would be easier to shrink back from that frontier... But I believe the times demand invention, innovation, imagination, decision. I am asking you to be the new pioneers on that New Frontier. (White, The New Frontier 81)

In the imagination of modern America, the West has come to stand for independence, self-reliance and individualism. Rhetorically at least, modern westerners see themselves as part of a lineage that conquered a wilderness and transformed the land, springing from a people who carved out their own destiny and remained beholden to no one, with an absolute belief in individualism.

This is an odd and interesting image, because more than any other section of the United States, the American West is a creation not so much of individual or local efforts, but of federal efforts. The government guided and molded settlement in the West. The armies of the federal government conquered the region, agents of the federal government explored it, federal officials administered it and federal bureaucrats tried to supervise the division and development of its resources. All of the American West outside of Texas and California, whose early statehood place them in a different category, was at some stage of its history a territory (i.e. a sort of colony) of the United States. The federal government controlled the governments of the territories and withheld from their citizen rights and privileges held by American citizens elsewhere. 


\section{DISENCHANTMENT WITH “THE GARDEN IN THE DESERT”}

We notice a drastic change of mood in critical interpretation. If the historians between 1890 and 1960 had viewed the West as a positive and constructive force in American civilization, the generation after 1960 reflected a profound negativism and disenchantment: in their view, the cultural values which Americans had used to develop the West had a destructive impact. Their task, as they saw it, was to chronicle this destruction.

Patricia Limerick's Legacy of Conquest: The Unbroken Past of the American West (1987), presented an anti-Turnerian interpretation of Western development. She provided a frontier story characterized not by the positivism that Turner saw in settlers' language, but by the conquest and imperialism they were trying to hide. Patricia Limerick also speaks about the fact that Turner's frontier thesis completely left out the minorities - whether gender or ethnic minorities. Limerick comes with the idea that the term "borderland" is more appropriate for the representation of a more complex cultural reality (Limerick 222).

Patricia Limerick also criticizes the frontier thesis as an egalitarian democratic symbol of progressivism, by addressing the destruction of the West's natural environment, the diversion of rivers, the mindless use of technology to change the natural ecology of the West, whether by water diversion or destruction of wildlife and their habitats. It would result in eventual exhaustion of scarce waters, the silting and salting of the soil, the destruction of valuable species of animals, and such a serious disruption of ecological balance that it might take centuries to repair, if ever.

Like Patricia Limerick, Richard White also takes a revisionist's stance against Turner. White acknowledges that Turner left out certain elements - such as the Indians - but he does not use this as a reason to dismiss what Turner had to say. While he admits that Turner's ideas were not entirely the product of his own research (similar views of frontier exceptionalism had been circulating in the years prior to Turner), he does give him credit for popularizing them. Turner's ideas must not be taken by themselves, but in conjunction with other views on the history and significance of the frontier. In It's Your Misfortune and None of My Own, A History of the American West (1991), White attempts to define the West as an autonomous physical region west of the Missouri River, and not as a part of the frontier process presented by Turner.

In conclusion, the West provided an arena for the expansion of federal powers that was available nowhere else in the United States. By exercising power, the government developed it. But the political reality often came against the myth of the gritty individualist, of the rugged frontiersman. The New Historicism approach writes at length about the destruction of earlier native cultures, of ethnic and racial conflicts, of the white Anglo exploitation of blacks, 
Indians and Hispanics, of the suppression of Orientals and the subordination of women at the hands of men, and deconstructs Turner's "frontier thesis" as a democratic principle.

\section{HOW CAN A SENSE OF PLACE SURVIVE?}

How, in the face of all this movement and intermixing, can we retain any sense of a local place and its particularity? An idealized notion of an era when places were (supposedly) inhabited by coherent and homogeneous communities is set against the current fragmentation and disruption. A desire for fixity and for security of identity in the middle of all the movement and change. A sense of place, of rootedness, can provide - in this form and on this interpretation stability and a source of unproblematic identity.

The mythical West provided the perfect symbol for Americans to rally around when confronted by national threat: The Great Depression and World War 2. This explains the popularity of westerns in these periods. The Western provided the unifying myth in an era when national crises demanded consensus. It demonstrated that Americans could succeed if they remained true to the spirit of the Old West. Like mythical westerners, Americans had to retain their selfreliance, independence and sense of mission by connected to the moral code represented by the West.

Occasionally, it has been part of what has given rise to defensive and reactionary responses - certain forms of nationalism, sentimentalized recovering of a sanitized "heritage". The West is the most strongly imagined section of the United States. A state of mind rather than a region, the West depends on the cultural baggage of the beholder. Few came to discover what there was to see in the real West. Rather they came with ideas about what they hoped to find. The mythical West imagined by Americans has shaped the West of history just as the West of history has helped create the West Americans imagined. The two cannot be neatly severed. People's intentions and actions are often shaped by cultural myths.

The mythical West of the imagination is not constructed through any conception of western regional diversity; instead, it is derived from the application of near-intangible generalities to "the West", such as striking, colorful vistas, romantic yet challenging landscapes; breathtaking frontier dramas. The West in this context becomes nothing less than the American Dream set against the quintessential American background.

The West became the center for the media's imaginative attentions in part because Americans had already assigned significant symbolic meaning to westering. Americans significantly associated freedom and independence with the borders of their own society, and they attached these values most fully to single males without permanent connections with family or society. Western 
heroes are wild and uncontrolled, because they lived at the limit of civilization. Domesticating this natural male violence became part of the mythical agenda of westering.

Myths speak through images rather than words. Words classify and separate, while images synthesize meaning in a way that interrelates and unifies. When the images of myth acquire special cultural significance and general recognition, they become cultural icons. When these images reveal the way of seeing and the basic attitude of a nation, they become emblems of national experience and help us understand the nature of that nation's sensibility. The Western, with its cultural icons, explains America to us and help us understand it.

Cultural images are symbols which every member of society, regardless of education or social level, recognizes at once. Cultural images suggest to the members of a social group a special conception of themselves, and tend to impose on them definite notions of what is good and what is desirable in social policy. Cultural images define the sense of the past which is common to the members of a culture. They are the principal form in which knowledge of the past operates in society.

The experience of sharing these images is one of the major forces of social cohesion, because the images express value judgments that everyone is expected to endorse. Cultural images evolve in step with the ideology that supports them. They are reshaped by the evolution of ideology and taste. They can be revised and updated to reflect the evolutionary trends of cultural development.

The American West offered the earth sciences outstanding opportunities and an ease of access to geologic information not available in the East or Europe. It was from the West, for example, that fossils were excavated to offer brilliant confirmation to Darwin's theory of evolution. The West gave American geology an unrivaled opportunity for the decipherment of earth history, and by the early twentieth century an "American school" of geology had developed, with accomplishments recognized throughout the world.

Geologists look to the Grand Canyon, for example, from the point of view of a very long time-span, one almost commensurate with the age of earth itself. The Grand Canyon is a "great natural laboratory" that is of value not only to America, but to civilization itself. The Grand Canyon - its exploration, the descent through the Colorado canyons by John Wesley Powell - became one of the epic sagas of the West. To go through the canyon, Major Powell braved the gushing cataracts and muddy torrent of the Colorado River in 1869. The journey provided fodder for the romantic imagination.

The deep recesses of the Grand Canyon reveal layer upon layer of deposition, uplift, redeposition and the agonizingly slow process of erosion from perhaps the most dramatic reminder of what geologic time means. Geological 
time is as vast as astronomical space. The Grand Canyon is a cross-section of earth history, a bit of the American West which exemplified the meaning and enormity of geologic time like nothing else on the globe. It is no wonder that landscapes like the Grand Canyon have become a symbol of American grandeur and a matter of national pride.

The West as seen in monumental images has come to stand for the idea of American bigness. Iconic American places such as the Grand Canyon, Yosemite, Monument Valley have come to be regarded as proof of American exceptionalism, as geographical manifest destiny. Wilderness becomes a national symbol, a sacred remnant of god's handiwork, a celebration of nonIndian wilderness. Western monumentalism regards landscape as cultural spectacle, as a natural wonderland which creates a national aesthetic. In this context we cannot help noticing the relationship of National Parks to American cultural nationalism and the forging of an American identity.

The grandeur of representation of the mountains, the vastness of the subject, demands wide stretches of canvas, so that the eye could absorb any detail and wander here and there, getting the impression of absolute freedom. The translator of the Romantic Sublime in American terms, the painter Albert Bierstadt became the orchestrator of dramatic landscape scenes, which exaggerated the vertical thrust of the mountains to achieve the monumental grandeur which Americans had come to expect from their continent. The Far West memorialized by Bierstadt was a region of psychological transfiguration, a liminal space (border space) demonstrating how the American wilderness masters the colonist. Everything is overstated with a hyperbolic logic and a dramatic feeling which refuses common sense and moderation. Melodramatic surfaces are asked to bear an excess of meaning. A lawless world that evokes too much emotional fervor, too much astonishment at the sensational, the lurid and the extravagant. Stirring atmospheric effects, dizzying volumes and stark contrasts. Stark abysses, brilliant ascents, gigantic trees, blazing reflections, impassable and impossible terrains which remind us of nothing so much as of our dreams.

In Sunset in the Yosemite Valley (1868), light emerges from the center of the canvas, hot enough to be molten lava burning a hole through the cosmos. Yet without the title, the time of day remains indeterminate, anticipating the kind of day-for-night shots produced through filters by cinematographers. The sun appears too high and bright for actual sunset, and the valley is too dark, even with low-lying wisps of clouds. The granite mountains rise out of blinding brightness to tower over the sides of the canvas in Bierstadt's signature mode. The painting's stunning effect is unreal, excessive, overdone.

Bierstadt altered actual sites as he wished, working much as a stage designer assembling some fantastic set. He indulged in dramatic excess. A mixture of topographical features organized for theatrical effect rather than for 
referential accuracy. He created composite landscapes in which half a dozen centers of interest vie for the viewer's attention in a kind of cinematic competition.

There is no actual view which corresponds to his Rocky Mountains, Lander's Peak (1863) for example, but this did not matter for Bierstadt's audience. Far misty crags rising behind a glassy lake and its waterfall, brilliantly lit by a shaft of sun in the middle distance; a Native group of tipis set amid a majestic mountainous landscape; small Indian figures set in a primeval landscape unspoiled by civilization, where the White Man could learn something at the time of the bloody Civil War.

In his oil on canvas Among the Sierra Nevada Mountains, California (1868) - Bierstadt gave much attention to details, even in the reflection on the water. The sensation of majesty and impressive grandeur is realized by contrasting the great mountains with the human being, or with a buffalo, a tiny canoe or, in this case, with a herd of deer that has come to drink from the mirrorlike mountain lake. The contrast between the massive escarpments and these tiny elements establishes the enormous scale of the landscape, so that the viewer does not lose himself in the landscape physically, but emotionally.

Bierstadt poured all his rhetoric into this canvas, seen with a "God's eye view" from an overlook. We can see the early morning sun burning through the vapors above the lake; the grim ramparts of rock, the stand of sequoias (the biggest trees in the world are dwarfed by the scale of the landscape) and the brilliant blue eye of the lake.

In order to protect American landscape, you have to "create" it first artistically, to make the public aware of its beauty and of the need to protect it. Bierstadt's mighty canvases would forever popularize the same breathtaking Yosemite vistas, and immortalize the West as a sublime, natural paradise, a wonderland for the traveler and the tourist, to be discovered and experienced in its romantic splendor.

Shortly after Bierstadt's visit to Yosemite in 1867, the place was set aside for public use, resort and recreation in a bill passed and signed by President Lincoln. The idea that any part of the West could be blotted out by industry would have seemed barely conceivable to its admirers, but it had come to pass. Except in the national parks, the Western landscape by 1890 started to be disfigured by mining, clear-cutting, damming, railroad construction, and pollution.

The U.S. government's policy of slaughtering the buffalo herds of the plains had destroyed the food base of the Plains Indians. The near extinction of the buffaloes prompted Albert Bierstadt to paint, in 1889, The Last of the Buffalo. It shows no white hunters with rifles. The blame for the ecocide is put on the Indians themselves. Bierstadt painted not the real West but a drop cloth for the Western, as a place waiting for characters and plots of the sort that took 
shape in the paintings of Frederic Remington and Charles Russell, and in the stories of Bret Harte and Owen Wister.

But the monumental landscape of the American West did not find expression only in the painting of Albert Bierstadt. Later in the 20th century there was a need for strengthening American identity and American nationalism (in the period around Word War 2), and the monumental West the perfect instrument - a cultural treasure trove.

We could say that John Ford's trademark image is Monument Valley, the monumental landscape which reappears in most of his Westerns. For example in Stagecoach, the coach is framed against a commanding view of Monument Valley that stretches out like a phantasm. The towering buttes (including the Mittens), immense mesas, jutting outcroppings, all posed against a broad expanse of desert: the vertical and horizontal planes of landscape seem to defy each other in a vertiginous setting that Ford would repeat in ten other Westerns, that would regularly be copied by other movie-makers, a landscape that has since become the stereotype of the Far West. Into the midst of this Bierstadtian landscape comes the cowboy outlaw in the person of Ringo Kid (John Wayne), twirling his Winchester, challenging the stage to stop (even as the camera zooms in on him at close range). With Ringo's addition to the passengers as a mediating figure, the democratizing process of regeneration can begin. Throughout the film moreover, the Americanizing process is defined by identification with a landscape that is itself lent a heroically national cast - in part through sheer immensity, in part through the Apaches who peer down in domination, from the heights.

The statistics of Monument Valley explain why horsemen and houses look diminutive in its midst. Its buttes, arches, towers and mesas soar abruptly over a thousand feet towards the inescapable sun. in prehistoric times, the area was in a state of volcanic upheaval. The gigantic sculptures of time and weather make the efforts of man appear irrelevant and vain.

Like Bierstadt, Ford recreates the spirit of the West at the expense of strict geographical authenticity. For example, in the movie My Darling Clementine the real Tombstone lies almost 400 miles south of Monument Valley. But Wyatt Earp remarks that his brother Morg is "riding shot at Tucson" and it sounds like a nearby cow town, but in fact Tucson is more than 300 miles south of Ford's location. Ford builds his own mythical West, underpinned by the tension between the frontier west and the flawed, irresolute East as embodied by Clementine and Doc Holiday. For John Ford, legends were more interesting than drab reality. Art does not aim to duplicate reality. Art provides an image of feeling; it gives objectified form and visibility to feeling -John Ford's westerns do that. 
Ford's westerns can be seen as mythical quests. They are journeys from East to West, going from civilization to wilderness. The characters in a Ford western are involved in the mythical carving of greatness from a hostile wilderness. Ford's people look small against the background of the mountains of monument Valley. It is the heroic saga that built America. And his people are larger than life and heroic.

\section{CONCLUSION}

The West reflects the American experience not so much as it really was, but as how Americans would like it to be. A myth is an encoded set of metaphors with a central function central in the societies that produced them. Myths give meaning to the world. In this sense a myth about the West is a story that explains who westerners (and Americans) are helps establish their identity. It speaks directly to American ideals, values, needs and goals. It combines other American beliefs involving national purpose, individual freedom, success and the superiority of the common people. Anyone who seeks to understand the United States has first to understand the story of the West, because the West is critical in the creation of American identity.

The American West presents a panoply of symbols that have been used in the formation of national identity. Space, not place, tantalized Americans when the frontiers were open and resources appeared limitless. Space is abstract. It lacks content; it is broad, open, and empty, inviting the imagination to fill it with substance and illusion; it is possibility and beckoning future. Place, by contrast, is the past and the present, stability and achievement". Place is "the construct of human experience", it is "the human home in the cosmic scheme of things". (Tuan 161)

A close look at the West as a place reveals its synthetic quality. This quality does not produce singular outcomes although it typifies all places. Rather, its multidimensionality permits the creation and evolution of a multitude of distinct places. In conclusion, the American West is an imaginary construct more than a material reality that can be measured in facts and figures. It is a conglomerate of Wests rather than a single West, a "succession of wests" constructed by symbolic means, an ever-shifting construct, a movable frontier that nevertheless has played a pivotal importance in the formation of American identity.

\section{Works Cited}

Adams, Paul C. Textures of Place: Exploring Humanist Geographies. The University of Minnesota Press, 2001. Print. 
Gallagher, Tag. John Ford: The Man and His Films. University of California Press, 1988. Print.

Goetzmann, William. The West of Imagination. University of Oklahoma Press, 2009. Print.

Hughes, Robert, American Visions. London: The Harvill Press, 1998.

Kaminsky, Stuart. American Film Genres. Chicago: Nelson Hall, 1984

Limerick, Patricia Nelson. The Legacy of Conquest. New York: Norton \& Co, 1987.

Slotkin, Richard. Gunfighter Nation: The Myth of the Frontier in Twentieth-Century America. University of Oklahoma Press, 1992. Print.

Smith, Henry Nash. Virgin Land: the American West as Symbol and Myth. Harvard University Press, 1970. Print.

Tuan, Yi-Fu. "Place: An Experiential Perspective”. In Geographical Review, 65 2, 151165. Print.

White, Richard. It's Your Misfortune and None of My Own: A History of the American West. Norman: University of Oklahoma Press, 1991. Print.

White, Richard and Patricia Nelson Limerick. The Frontier in American Culture. University of California Press, 1994. Print.

Wood, Gordon. The Empire of Liberty. Oxford University Press. 2009. Print. 